\section{Evaluasi Faktor Penyebab Keterlambatan Kerja Pada Proyek Pekerjaan Pembangunan Penggantian Jembatan Sei. Ata IV di Kabupaten Tanah Bumbu Kalimantan Selatan}

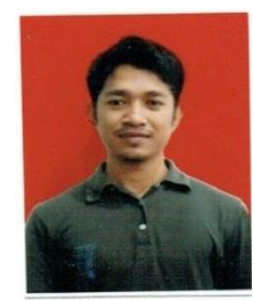

\section{Achmad Romdan, ST.}

Achmad Romdan, ST lahir di Banjarmasin, 11 Juni 1989. Pendidikan terakhir Universitas Lambung Mangkurat 2008 2013, sekarang bekerja di bidang konstruksi jalan dan jembatan sebagai Konsultan Supervisi. buletinppi@ulm.ac.id

\section{Pendahuluan}

Sebubungan dengan meningkatnya jumlah penduduk serta taraf hidup masyarakat sehingga mengharuskan pemerintah pusat maupun daerah untuk memperbanyak dan meningkatkan fasilitas umum, seperti: pembangunan sarana dan prasarana transportasi, kesehatan, pendidikan serta pemerintahan.

Kegiatan ini dilaksanakan karena sarana dan prasarana bangunan konstruksi jembatan Sei. ATA IV yang terdahulu tidak layak pakai untuk dilalui oleh jalur lalulintas untuk umum dan tidak dapat digunakan secara maksimal, maka dilaksanakanlah Proyek Penggantian Pembangunan Jembatan Sei. Ata IV ini dengan menggunakan dana APBN tahun 2017.

\section{Hasil Kerja}

Dari hasil pengumpulan data didapatlah 25 faktor penyebab keterlambatan kerja. Kemudian hasil pengumpulan data tersebut dianalisa dan dijadikan kuesioner untuk dijawab oleh 20 responden yang terlibat di lokasi proyek. Hal tersebut dilakukan untuk mencari faktor yang paling berpotensi terhadap keterlambatan untuk tingkat keseringan dan level dampak pada proyek Penggantian Pembangunan Jembatan Sei. Ata IV. Untuk mencari peringkat dari faktor tersebut dapat dilihat dari hasil pengisian kusioner pada jawaban-jawaban responden yang dianggap ekstrim (skor 5 dan 6) untuk level frekuensi dan level dampak. Jawaban responden tersebut
Pembangunan sarana dan prasarana transportasi, kesehatan, pendidikan serta pemerintahan. Kegiatan ini dilaksanakan juga pada pembangunan Jembatan Sei. Ata IV yang terdahulu tidak layak fungsi serta banyaknya kerusakan pada struktur bawah dan atas bangunan yang ada sehingga tidak memadai untuk digunakan secara maksimal Proyek Penggantian Jembatan Sei. ATA IV. Berdasarkan indentifikasi dilapangan penyebab keterlambatan Penggantian Jembatan Sei. ATA IV dengan metode RRI dengan nilai (>) 0.400 yaitu kondisi cuaca yang tidak terduga sebelumnya, kekurangan tenaga kerja/personil, kekurangan peralatan, kesalahan yang terjadi selama pelaksanaan proyek sehingga harus dikerjakan kembali, prediksi terhadap lokasi lapangan atau geografis proyek, terlambat membayar upah pekerja, dan faktor-faktor yang paling dominan yang menyebabkan keterlambatan dalam pengerjaan proyek tersebut. Berdasarkan indentifikasi di lapangan faktor-faktor yang paling dominan yang menyebabkan keterlambatan dalam pengerjaan proyek tersebut adalah lambatnya dalam proses pembebasan lahan pada lokasi pekerjaan, sering terjadinya perubahan desain pada item-item tertentu, terlambat membayar upah pekerja, adanya pekerjaan yang ditiadakan dan ditambahkan, sehingga terjadi perubahan volume pekerjaan

www.buletinppi.ulm.ac.id

kemudian dianalisis menggunakan program SPSS (versi $16,0)$ untuk faktor yang berpotensi menyebabkan keterlambatan. Jawaban responden terhadap kuesioner diolah dengan mencari nilai Relative Rank Indeks (RRI) masing-masing jawaban untuk tiga variabel yaitu tingkat frekuensi terjadinya faktor, level dampak terhadap keterlambatan, dan nilai indeks kritis. Dengan menggunakan program Microsoft Excel 2007 diperoleh hasil akhir berupa ranking dari faktorfaktor tersebut.

Adapun 25 faktor yang terdapat dalam Kuesioner tersebut antara lain adalah sebagai berikut (dapat dilihat pada Lampiran 1:

\section{Status Responden Di Proyek}

\section{STATUS RESPONDENDI PROYEK}

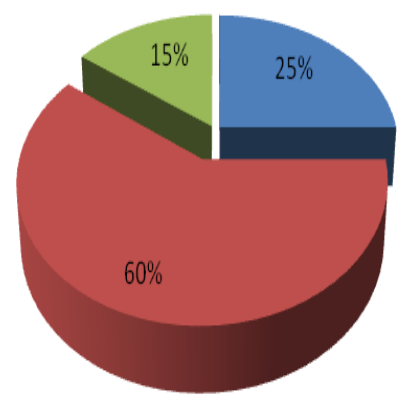

- Konsultan Pengawas

- Tenaga Teknis Kontraktor

- Tenaga Teknis (PU) 
Dari hasil distribusi kuesioner, diperoleh hasil bahwa status responden di proyek sebanyak $25 \%$ Konsultan Pengawas (5 responden), 15\% Pengelola Teknis PU (3 responden), dan 60\% Tenaga Teknis Kontraktor (12 responden).

Dari hasil analisis dan pengisian responden, kemudian dihubungkan dengan apa yang dilihat langsung di lapangan, hal tersebut dilakukan untuk mengetahui tingkat kebenaran alat ukur (kuesioner) terhadap subyek penelitian yang terjadi di lapangan. Analisis tersebut dapat diukur dengan cara membandingkan hasil pengisian kuesioner yang dilakukan responden dengan yang terjadi di lapangan, dari hasil perbandingan tersebut dapat dikatakan bahwa hasil pengisian kuesioner oleh responden dapat dipercaya.

Dari hasil analisis kuesioner tersebut di atas, diperoleh hasil rangking faktor-faktor berdasarkan nilai indeks kritis, Tingkat Frekuensi, dan Level Dampak terhadap masing-masing faktor pada proyek yang diteliti, antara Lain :

- Kondisi cuaca yang tidak terduga sebelumnya (C19)

Berada pada peringkat pertama (1) untuk nilai Indeks Kritis dan Tingkat Frekuensi, dan peringkat keempat (4) pada level dampak. Kondisi cuaca yang tak terduga sebelumnya merupakan faktor yang frekuensinya paling sering terjadi selama pelaksanaan proyek dan hampir memberi dampak terhadap keterlambatan proyek yang diteliti (data curah hujan harian).

- Kekurangan tenaga kerja atau personil (B6)

Berada pada peringkat kedua (2) berdasarkan nilai Indeks Kritis dan tingkat frekuensi, dan untuk level dampaknya berada pada peringkat pertama (1).

Ini menunjukkan bahwa kekurangan tenaga kerja atau personil sangat memberi dampak terhadap keterlambatan proyek. Menurut responden, dalam hal ini pengguna jasa (kontraktor) mengalami kekurangan tenaga kerja atau personil, karena penyebabnya adalah ketidakpatuhan terhadap kontrak kerja yang telah disepakati bersama, lagi-lagi karena kontraktor menginginkan keuntungan yang besar dengan cara mengurangi tenaga kerja atau personil.

- Kekurangan peralatan (B3)

Berada pada peringkat ketiga (3) untuk nilai indeks kritis dan tingkat frekuensi, dan peringkat kedua (2) untuk level dampak. Akibat utama kekurangan peralatan di lokasi pekerjaan terkadang terjadi akibat alat yang digunakan mengalami kerusakan sehingga harus menunggu untuk diperbaiki. Hal tersebut mengakibatkan faktor kekurangan peralatan masuk kedalam delapan (8) peringkat penyebab keterlambatan pada proyek Penggantian Pembangunan Jembatan Sei. Ata IV

- Kesalahan yang terjadi selama pelaksanaan proyek sehingga harus dikerjakan kembali (B4).
Pada peringkat keempat (4) ditempati oleh faktor kesalahan yang terjadi selama pelaksanaan proyek untuk nilai Indeks Kritis, dan peringkat ketiga (3) untuk tingkat frekuensi maupun level dampak. Menurut responden, hal ini terjadi karena adanya kesalahan dalam pelaksanaan beberapa item pekerjaan sehingga pekerjaan harus dikerjakan kembali.

- Prediksi terhadap lokasi lapangan atau geografis proyek (D24).

Berada pada peringkat kelima (5) untuk nilai indeks kritis, dan peringkat keempat (4) tingkat frekuensi maupun level dampak. Menurut responden ini terjadi karena kesalahan dalam menentukan batas maksimal keras lapisan tanah dasar untuk proses pemancangan tiang pondasi, sehingga berakibat terhadap keterlambatan proyek.

- Faktor terlambat membayar upah pekerja (B10). Berada pada peringkat keenam (6) untuk nilai Indeks kritis, peringkat keempat (4) untuk tingkat frekuensi dan peringkat kelima (5) untuk level dampak. Menurut responden hal ini disebabkan adanya keterlambatan dalam hal pencairan dana sehingga kontraktor mengalami kesulitan keuangan.

- Perencanaan yang kurang lengkap (A1).

Berada pada peringkat ketujuh (7) untuk nilai indeks kritis, peringkat keempat (4) untuk tingkat frekuensi dan peringkat keenam (6) untuk level dampak. Menurut responden, hal ini disebabkan oleh adanya kesalahan dalam pembuatan design gambar terhadap tahapan pengerjaan awal pembuatan jembatan.

\section{Kesimpulan}

a. Faktor-faktor yang paling berpotensi menyebabkan keterlambatan kerja berdasarkan nilai level dampak pada metode RRI dengan nilai (>) 0.400 yaitu :

1. Kondisi cuaca yang tidak terduga sebelumnya.

2. Kekurangan tenaga kerja/personil.

3. Kekurangan peralatan.

4. Kesalahan yang terjadi selama pelaksanaan proyek sehingga harus di kerjakan kembali.

5. Prediksi terhadap lokasi lapangan atau geografis proyek.

6. Terlambat membayar upah pekerja.

7. Perencanaan yang kurang lengkap.

b. Berdasarkan Hasil identifikasi yang dilakukan faktor paling dominan yang menyebabkan keterlambatan kerja secara keseluruhan adalah:

1. Lambatnya dalam proses pembebasan lahan pada lokasi pekerjaan.

2. Sering terjadinya perubahan desain pada item-item tertentu.

3. Terlambat membayar upah pekerja.

4. Adanya pekerjaan yang ditiadakan dan ditambahkan, sehingga terjadi perubahan volume pekerjaan. 


\section{Ucapan Terimakasih}

Ucapan terimakasih kepada ALLAH SWT, yang telah memberikan rahmat dan karunianya, kepada orang tua yang telah memberikan dukungan, istri tercinta yang selalu menemani, kerabat dan sahabat yang telah membantu pembuatan artikel ini, kepada semua karyawan, personil, pekerja pada proyek Peggantian Jembatan Sei. ATA IV yang telah banyak membantu dalam data sekunder dan primer serta menjadi objek penelitian saya.

\section{Referensi}

1. Arditi dan Patel. 1989. "Impact Analysis of Owner".dkjaf

2. Assaf et al. 1995. Causes of Delay in Large Building Contruction Project.

3. Direktorat Jendral Bina Marga. Balai Besar Pelaksana Jalan Nasional Kalimantan Selatan

4. Kusjadmikahadi, R. Amperawan, 1999.Studi Keterlambatan Kontraktor Dalam melaksanakan Proyek Konstruksi di Daerah Istimewa Yogyakarta.

5. Levis dan Atherly. 1996. "Delay Construction"

6. Selaras Mandiri Sejahtera, PT. 1993. "Petunjuk Pelaksanaan Pekerjaan". Badan Penerbit PT. Selaras Mandiri Sejahtera, Banjarmasin.

7. Sugiyono, (2008). Metode Penelitian Kuantitatif Kualitatif dan R\&D. Bandung Alfabeta. 